\title{
COPEPOD COMMUNITY STRUCTURE OF THE WINTER FRONTAL ZONE INDUCED BY THE KUROSHIO BRANCH CURRENT AND THE CHINA COASTAL CURRENT IN THE TAIWAN STRAIT
}

Yang-Chi Lan

Fishery Research Institute, Keelung, Taiwan, R.O.C.

Ming-An Lee

Department of Environmental Biology and Fisheries Science, National Taiwan Ocean University, Keelung, Taiwan, R.O.C., malee@mail.ntou.edu.tw

Cheng-Hsin Liao

Department of Environmental Biology and Fisheries Science, National Taiwan Ocean University, Keelung, Taiwan, R.O.C.

Kuo-Tien Lee Department of Environmental Biology and Fisheries Science, National Taiwan Ocean University, Keelung, Taiwan, R.O.C.

Follow this and additional works at: https://jmstt.ntou.edu.tw/journal

Part of the Aquaculture and Fisheries Commons

\section{Recommended Citation}

Lan, Yang-Chi; Lee, Ming-An; Liao, Cheng-Hsin; and Lee, Kuo-Tien (2009) "COPEPOD COMMUNITY STRUCTURE OF THE WINTER FRONTAL ZONE INDUCED BY THE KUROSHIO BRANCH CURRENT AND THE CHINA COASTAL CURRENT IN THE TAIWAN STRAIT," Journal of Marine Science and Technology. Vol. 17: Iss. 1, Article 1.

DOI: $10.51400 / 2709-6998.1970$

Available at: https://jmstt.ntou.edu.tw/journal/vol17/iss1/1

This Research Article is brought to you for free and open access by Journal of Marine Science and Technology. It has been accepted for inclusion in Journal of Marine Science and Technology by an authorized editor of Journal of Marine Science and Technology. 
COPEPOD COMMUNITY STRUCTURE OF THE WINTER FRONTAL ZONE INDUCED BY THE KUROSHIO BRANCH CURRENT AND THE CHINA COASTAL CURRENT IN THE TAIWAN STRAIT

\section{Acknowledgements}

We thank the captain and crew of the Ocean Research vessel I and graduate students of this team of the Department of Environmental Biology and Fisheries Science, National Taiwan Ocean University, who helped with the collection of zooplankton samples and assemblage environmental data. This project (grant no. NSC90-2611-M-019-011-OP4) was financially supported by the National Science Council of Taiwan. 


\title{
COPEPOD COMMUNITY STRUCTURE OF THE WINTER FRONTAL ZONE INDUCED BY THE KUROSHIO BRANCH CURRENT AND THE CHINA COASTAL CURRENT IN THE TAIWAN STRAIT
}

\author{
Yang-Chi Lan*, Ming-An Lee**, Cheng-Hsin Liao**, and Kuo-Tien Lee**
}

Key words: copepod, diversity, Kuroshio, China Coastal Current.

\begin{abstract}
This study investigates the spatial distribution of copepods and its relationship with water masses across a frontal area induced by the China Coast Current and the Kuroshio Branch Current in the Taiwan Strait. Temperature and salinity was lower of stations showed significant stratification and lower in the China Coastal Current, but absent or higher in the Kuroshio Branch Current. In this study, 73 copepod species belonging to 36 genera, 18 families and 3 orders were identified. Assemblages of the copepods were divided into three groups KBG, MG and CCG, driven from cluster analysis and were associated with different water masses. Copepods were abundant in the group CCG $\left(53.5 \pm 18.5 \mathrm{inds} / \mathrm{m}^{3}\right)$ and in the frontal waters (MG, $\left.52.9 \pm 43.1 \mathrm{inds} / \mathrm{m}^{3}\right)$ than in the group KBG $\left(25.2 \pm 5.7 \mathrm{inds} / \mathrm{m}^{3}\right)$. Copepods were more diverse in the KBG and MG than in the CCG. Most of the dominant species in the KBG belong to warm water species, such as Acrocalanus gibber, Canthocalanus pauper, Clausocalanus furcatus, Clausocalanus minor and Clausocalanus mastigophorus. While the group CCG included indicator species such as Calanus sinicus and Ditrichocorycaeus affinis and coastal/neritic or widely distributed species. In the MG, Paracalanus parvus, Paracalanus aculeatus, Acrocalanus gibber, Ditrichocorycaeus affinis and Temora turbinata were dominant.
\end{abstract}

\section{INTRODUCTION}

The Taiwan Strait (TS) connects the East China Sea (ECS)

Paper submitted 04/10/07; accepted 07/03/07. Author for correspondence: Ming-An Lee (e-mail:malee@mail.ntou.edu.tw).

* Fishery Research Institute, Keelung, Taiwan, R.O.C.

** Department of Environmental Biology and Fisheries Science, National Taiwan Ocean University, Keelung, Taiwan, R.O.C. and South China Sea (SCS), and lead the seasonal hydrographic exchange between both of them driven by the seasonally monsoon system [21,23]. The northeast (NE) monsoon prevails and forces the waters of East China Sea flowing southward along the China coast into the Taiwan Strait in the form of the China Coastal Current (CCC) in winter [5, 23, 27, 29]. In the southeastern TS, the deep Penghu Channel (PHC) guides the Kuroshio Branch Current (KBC) intruding northward into the TS $[8-9,22-23]$. A zonal oceanic front is formed over the Chang-Yuen Ridge (CYR) where the CCC and the KBC meet $[21,27,29]$. In the TS, northward transport of the $\mathrm{KBC}$ is small or not persistent $[22-23,29,36]$ in contrast to the southward transport of the CCC [27] in winter.

Copepods are the most abundant zooplankton in the ocean and a main food source for marine fish larvae [17, 25-26, 37, 41]. Their abundance and distribution are known to be influenced by hydrographic conditions $[1,15,24,38]$, and they have been suggested to provide be good biological indicator species for water masses [44]. They are also the best biomarkers for trace metals monitoring marine environments [13].

Physical and chemical oceanography in the TS has been investigated fairly comprehensively in winter $[5,8-9,21-23,27$, 29, 36]. Several studies focusing on copepods have been done in the TS. Copepod composition in the vicinity of Tanshui River estuary [10, 14, 20, 39-40], northern TS [15-16, 24] and southern TS [18, 31-33] have been recorded. Hsieh et al. [16] reported the composition and distribution of copepods and larval fishes in relation to hydrographic factors. Transportation of copepods derived by specific currents have also been reported, such as Undinula vulgaris [43] and Calanus sinucus [19] being transported by the South China Sea Current and China Coastal Current, respectively.

Weather conditions of the study area during the NE monsoon season were usually rough, and therefore, sampling was difficult and dangerous in winter. The winter composition of copepods in the frontal area resulting from the $\mathrm{CCC}$ and the $\mathrm{KBC}$ has not been studied as yet. This study intended to examine the spatial distribution of copepods and its relationship with water masses 
Table 1. Locations, sampling times, copepod abundance, Shannon's diversity index and Simpson's evenness of each sampling station in winter 2002.

\begin{tabular}{lcccccccc}
\hline Stations: & ST1 & ST2 & ST3 & ST4 & ST5 & ST6 & ST7 & ST8 \\
\hline Longitude $\left({ }^{\mathbf{0}} \mathbf{E}\right)$ & $120^{\circ} 08^{\prime}$ & $120^{\circ} 12^{\prime}$ & $120^{\circ} 07^{\prime}$ & $120^{\circ} 00^{\prime}$ & $119^{\circ} 57^{\prime}$ & $119^{\circ} 54^{\prime}$ & $119^{\circ} 51^{\prime}$ & $119^{\circ} 51^{\prime}$ \\
Latitude $\left({ }^{\circ} \mathbf{N}\right)$ & $23^{\circ} 51^{\prime}$ & $24^{\circ} 20^{\prime}$ & $24^{\circ} 23^{\prime}$ & $24^{\circ} 24^{\prime}$ & $24^{\circ} 24^{\prime}$ & $24^{\circ} 22^{\prime}$ & $24^{\circ} 19^{\prime}$ & $24^{\circ} 01^{\prime}$ \\
Date & Jan. 4 & Jan. 4 & Jan. 4 & Jan. 4 & Jan. 4 & Jan. 4 & Jan. 4 & Jan. 5 \\
Time & $13: 25$ & $16: 48$ & $18: 56$ & $20: 26$ & $22: 02$ & $00: 12$ & $02: 02$ & $05: 09$ \\
Copepod abundance (inds $\left./ \mathbf{m}^{\mathbf{3}}\right)$ & 22.9 & 22.4 & 42.3 & 68.4 & 83.4 & 32.0 & 18.8 & 27.1 \\
Shannon's diversity index & 3.88 & 3.91 & 3.17 & 3.13 & 4.07 & 3.89 & 4.12 & 4.07 \\
Simpson's evenness & 0.73 & 0.80 & 0.72 & 0.64 & 0.81 & 0.75 & 0.82 & 0.74 \\
\hline
\end{tabular}

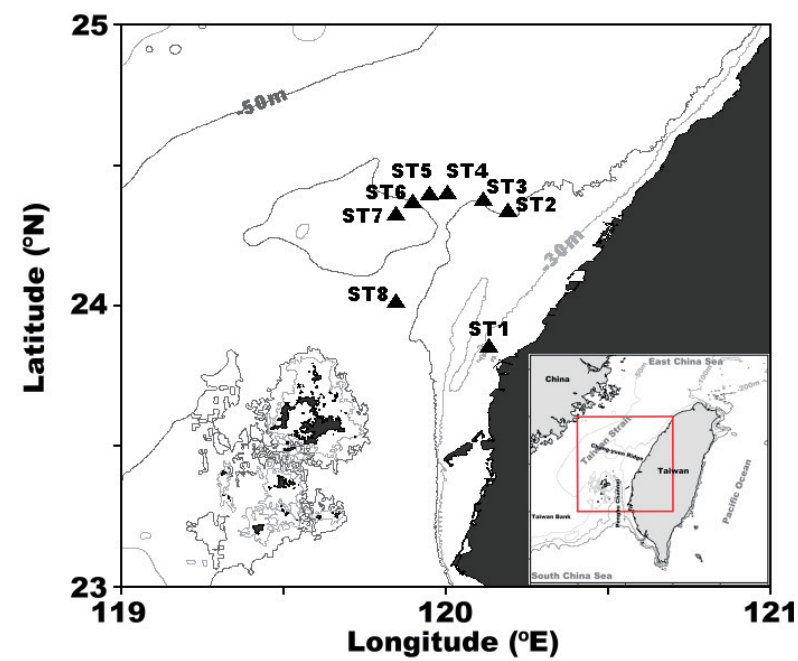

Fig. 1. Topography and locations of sampling stations (solid triangle) with isobaths at 30 and $50 \mathrm{~m}$ depth in this study area.

across the frontal area caused by the $\mathrm{CCC}$ and the KBC in TS.

\section{MATERIAL AND METHODS}

Copepods were collected with a Bongo plankton net during cruise 635 in January 2002 on board of the Ocean Research I (Fig. 1 and Table 1). Bongo net had a mouth diameter of $60 \mathrm{~cm}$, mesh size of $335 \mu \mathrm{m}$ and was towed obliquely. A flowmeter was mounted at the center of the net opening. The zooplankton samples were preserved in sea water with 5-10\% formalin.

At each station prior to collecting plankton, temperature and salinity at different depths were obtained by lowering a CTD profiler from the sea surface to a depth near the bottom. In the laboratory, each zooplankton sample was repeatedly divided with a Folsom splitter until its subsample containing 300-500 specimens of copepods. The specimens were sorted and identified to species if possible by using major references for the area $[3-4,7]$. NOAA satellites provide SST measurements from AVHRR showing the spatial distribution of surface temperature. AVHRR images with $1.1 \mathrm{~km}$ spatial resolution were obtained from the Department of Environmental Biology and Fisheries Science, National Taiwan Ocean University.

Shannon's diversity index was used to calculate the species

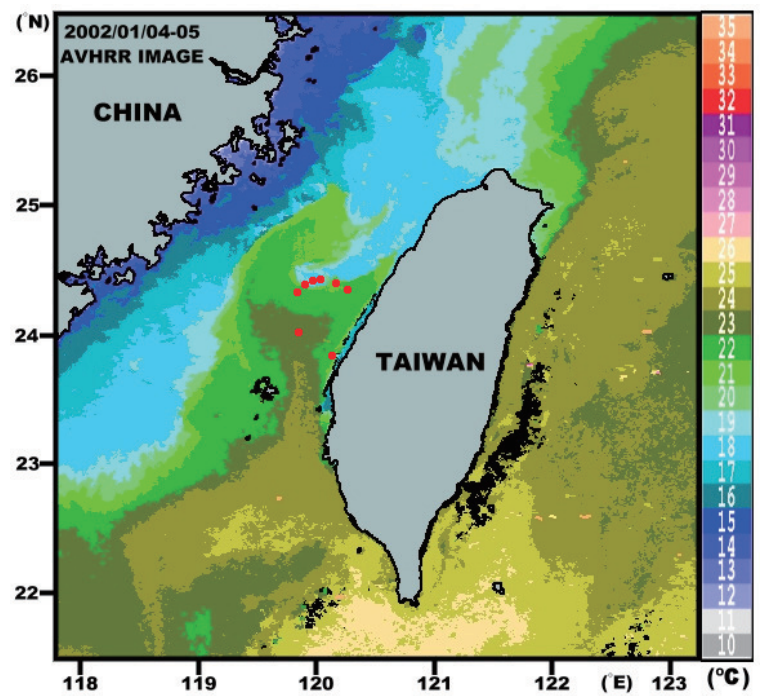

Fig. 2. Spatial distribution of the sea surface temperature derived from NOAA/AVHRR during sampling period. Sampling stations are marked as red solid circles are our.

diversity and Simpson's evenness was used to measure the relative abundance of species at each station $[2,34]$. Shannon's diversity index and Simpson's evenness were processed by the PRIMER (version 5) program. A cluster analysis with normalized Euclidean distances was used to measure the levels of similarity in species composition among the sampling stations, and Ward's method was used to illustrate their relations as a dendrogram. The cluster analysis was processed by the STATISTICA (version 6.0) program. Copepod abundance was transformed by logarithmic function $[\mathrm{Ln}(\mathrm{N}+1)]$ for cluster analysis.

\section{RESULTS}

\section{Hydrography}

Hydrographic parameters in the Taiwan Strait are highly influenced by the northeasterly monsoon in winter. Spatial distribution of the sea surface temperature derived from NOAA/AVHRR is useful for showing the hydrographic condi- 


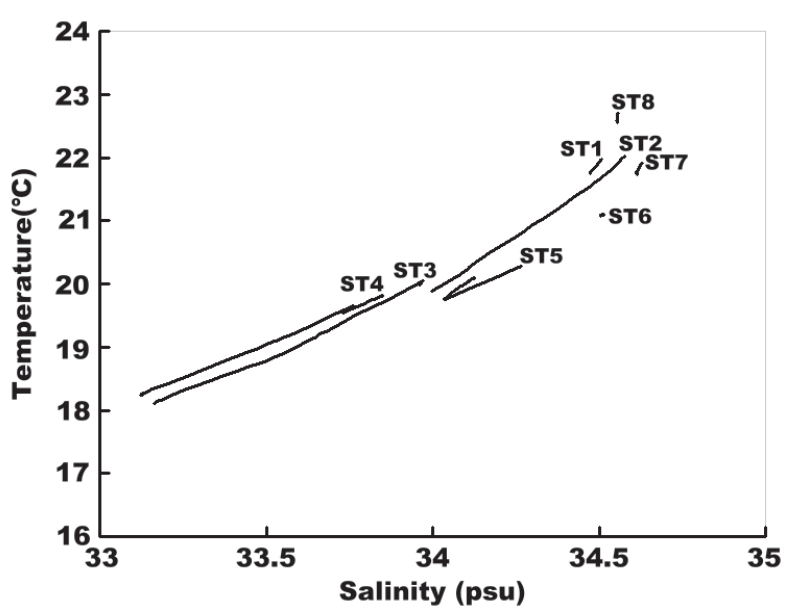

Fig. 3. Vertical temperature-salinity profiles at 8 sampling stations (ST1-8).

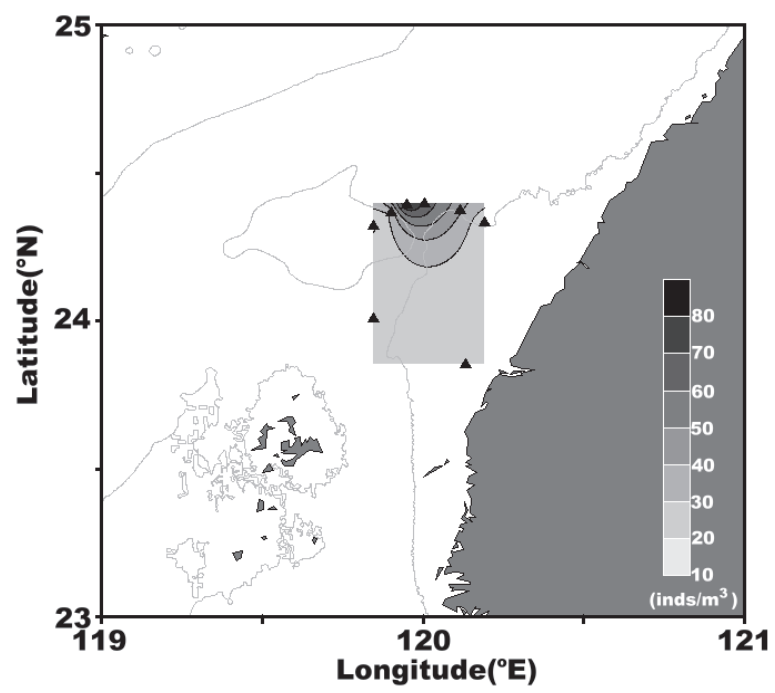

Fig. 4. Spatial distribution of copepod abundances (sampling stations as solid triangle).

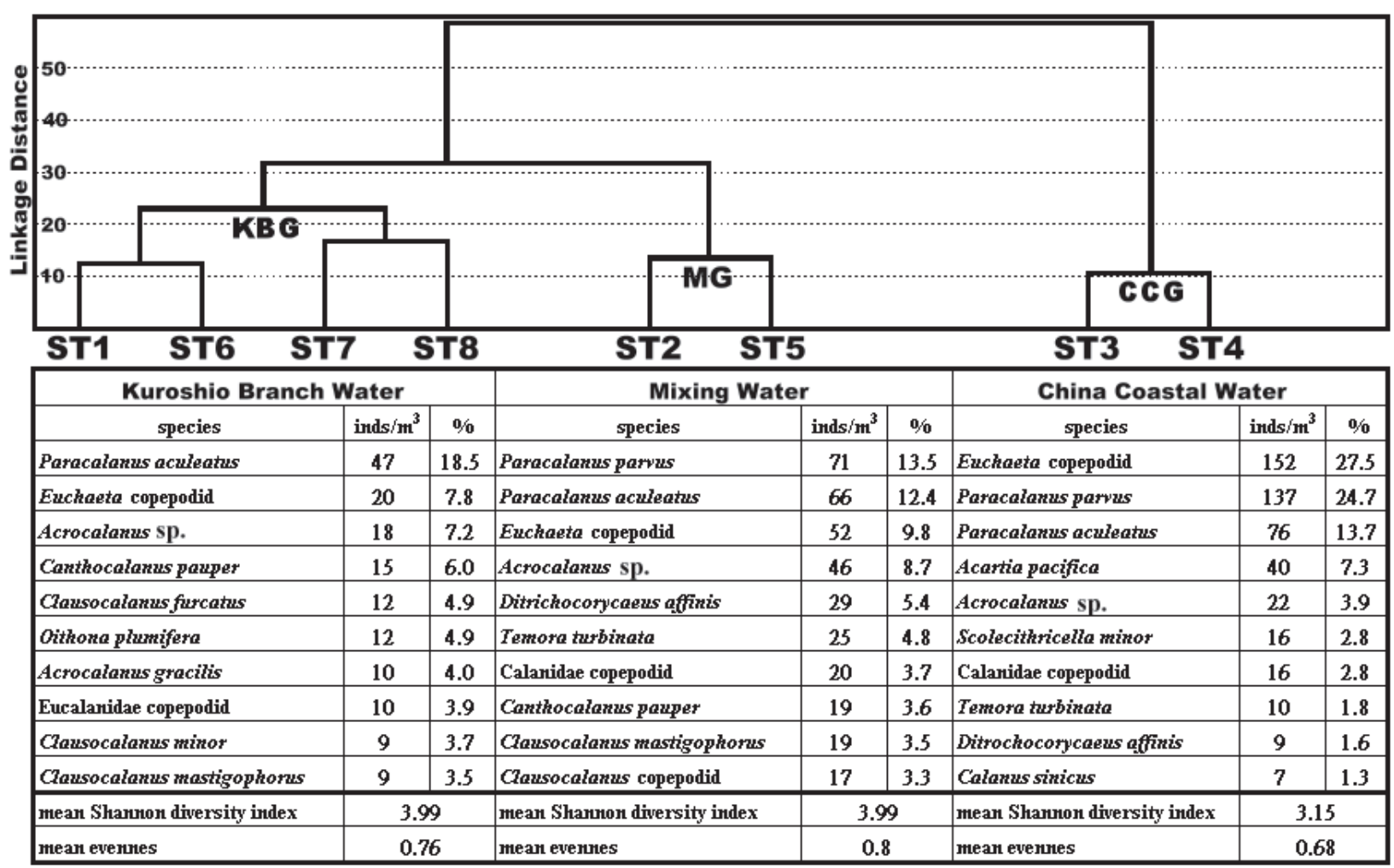

Fig. 5. Dengrogram resulting from cluster analysis based on the copepod communities of the 8 sampling stations in the Taiwan Strait, and the dominant species, mean Shannon diversity index and evenness of each grouped stations.

tion in our study period (Fig. 2). The steady and strong northeasterly winds push the freh, cold China Coastal Current southward. At the same time, the salty and warm Kuroshio Branch Current flowed northward through the Penghu Channel towards the Taiwan Strait. The KBC flows westward when it is blocked by the shallow CYR and the CCW in the middle of TS. Variations of temperature and salinity are steady and higher at stations located at the KBW (stations ST1, ST6, ST7, ST8; Fig.
3) in contrast to those in the CCW (stations ST3, ST4) and mixing waters (MW, stations ST2, ST5). Temperature and salinity of stations in the KBW varies from 21.0 to $22.8^{\circ} \mathrm{C}$ and 34.5 to $34.7 \mathrm{psu}$, respectively, and 18.0 to $20.0^{\circ} \mathrm{C}$ and 33.1 to 34 psu in the CCW. Vertical distributions of the temperature and salinity of stations show significant stratification phenomena in the $\mathrm{CCW}$, but are absent in the KBW. Temperature and salinity in stations located in the CCW show lowest value at the surface 
Table 2. Occurrences of copepods in difference waters. * $<$ half of $\mathbf{n}$; half of $\mathbf{n}<* *<\mathbf{n} ; * * * \mathbf{n}$; $\mathbf{n}$ are number of stations in each water.

\begin{tabular}{|c|c|c|c|c|c|c|c|}
\hline Species & FW & $\mathrm{CCW}$ & KBW & Species & FW & $\mathrm{CCW}$ & KBW \\
\hline \multicolumn{8}{|l|}{ ORDER : CALANOIDA } \\
\hline ACARTIIDAE & & & & EUCALANIDAE & & & \\
\hline Acartia danae & $* *$ & & $*$ & Paraeucalanus attenuatus & & $* *$ & \\
\hline Acartia hongi & $* * *$ & $* * *$ & $* * *$ & Rhincalanus rostrifrons & & $* *$ & $* *$ \\
\hline Acartia pacifica & $* * *$ & $* * *$ & $* *$ & Subeucalanus crassus & $* * *$ & $* *$ & $*$ \\
\hline AUGAPTILIDAE & & & & Subeucalanus mucronatus & $* *$ & & * \\
\hline Haloptilus mucronatus & & $*$ & & Subeucalanus subtenuis & & & \\
\hline CALANIDAE & & & & EUCHAETIDAE & & & \\
\hline Calanoides carinatus & & & $*$ & Euchaeta concinna & & $* * *$ & $* *$ \\
\hline Calanus sinicus & $* *$ & $* * *$ & $* *$ & LUCICUTIIDAE & & & \\
\hline Canthocalanus pauper & $* * *$ & $* * *$ & $* * *$ & Lucicutia curta & $*$ & & \\
\hline Cosmocalanus darwini & $* * *$ & & $* * *$ & Lucicutia flavicornis & $* * *$ & $* *$ & $* * *$ \\
\hline Nannocalanus minor & $* *$ & $* *$ & $* *$ & METRIDICIDAE & & & \\
\hline Neocalanus gracilis & & & $*$ & Pleuromamma gracilis & $* *$ & $* *$ & $* * *$ \\
\hline Neocalanus robustior & $* *$ & & $*$ & Pleuromamma robusta & & & $*$ \\
\hline Undinula vulgaris & $*$ & & $* *$ & PARACALANIDAE & & & \\
\hline CANDACIIDAE & & & & Acrocalanus gibber & $* * *$ & $* * *$ & $* * *$ \\
\hline Paracandacia bispinosa & & & $*$ & Acrocalanus gracilis & $* * *$ & $* * *$ & $* * *$ \\
\hline Paracandacia truncata & & & $*$ & Acrocalanus monachus & $* * *$ & & $* *$ \\
\hline CENTROPAGIDAE & & & & Calocalanus pavo & $* *$ & & $* *$ \\
\hline Centropages furcatus & & & $*$ & Paracalanus aculeatus & $* * *$ & $* * *$ & $* * *$ \\
\hline Centropages gracilis & & & $*$ & Paracalanus parvus & $* * *$ & $* * *$ & $* * *$ \\
\hline CLAUSOCALANIDAE & & & & PONTELLIDAE & & & \\
\hline Clausocalanus arcuicornis & $* *$ & $* * *$ & $* *$ & Calanopia minor & & & $* *$ \\
\hline Clausocalanus farrani & $* * *$ & $* *$ & $* *$ & Labidocera euchaeta & $*$ & & $*$ \\
\hline Clausocalanus furcatus & $* * *$ & $* * *$ & $* * *$ & SCOLECITHRICIDAE & & & \\
\hline Clausocalanus lividus & $*$ & & $* *$ & Scolecithricella abyssalis & & $* *$ & \\
\hline Clausocalanus mastigophorus & $* * *$ & $* *$ & $* * *$ & Scolecithricella minor & $* *$ & $* * *$ & $* *$ \\
\hline Clausocalanus minor & $* * *$ & $* * *$ & $* * *$ & Scolecithricella longispinosa & & $* *$ & \\
\hline Clausocalanus parapergens & & & $*$ & Scolecithrix danae & & & * \\
\hline \multirow[t]{3}{*}{ Ctenocalanus vanus } & $* *$ & & $* *$ & TEMORIDAE & & & \\
\hline & & & & Temora discaudata & $* *$ & & $* * *$ \\
\hline & & & & Temora turbinata & $* * *$ & $* * *$ & $* *$ \\
\hline \multicolumn{8}{|l|}{ ORDER:CYCLOPOIDA } \\
\hline Oithona plumifera & $* * *$ & $* * *$ & $* * *$ & Oithona similis & & & * \\
\hline Oithona setigera & & & $* * *$ & Oithona tenuis & & & $*$ \\
\hline \multicolumn{8}{|c|}{ ORDER : POECILOSTOMATOIDA } \\
\hline Agetus flaccus & & & $* *$ & Onychocorycaeus catus & & & $* *$ \\
\hline Agetus limbatus & & & $*$ & Onychocorycaeus pacificus & & $* *$ & $* *$ \\
\hline Agetus typicus & $* *$ & & $* *$ & Farranula carinata & & & $*$ \\
\hline Corycaeus clausi & & & $*$ & Farranula concinna & & & $*$ \\
\hline Corycaeus crassiusculus & $* * *$ & & $* *$ & Farranula gibbula & $* *$ & & $* *$ \\
\hline Corycaeus speciosus & $* * *$ & $* *$ & $* * *$ & ONCAEIDAE & & & \\
\hline Ditrichocorycaeus affinis & $* * *$ & $* * *$ & $* *$ & Oncaea conifera & & & * \\
\hline Ditrichocorycaeus andrewsi & & & $*$ & Oncaea mediterranea & & & $*$ \\
\hline Ditrichocorycaeus dahli & $* *$ & $* *$ & $* *$ & Oncaea venusta & $* * *$ & $* * *$ & $* * *$ \\
\hline Ditrichocorycaeus erythraeus & $*$ & & & SAPPHIRINIDAE & & & \\
\hline Monocorycaeus robustus & & & $*$ & Sapphirina angusta & & & * \\
\hline Onychocorycaeus agilis & $* * *$ & $* * *$ & $* *$ & & & & \\
\hline
\end{tabular}

and increase with depth.

\section{Copepod Assemblages}

Copepods were abundant at stations located at the CCC $\left(53.5 \pm 18.5 \mathrm{inds} / \mathrm{m}^{3}\right)$ and in the frontal waters $(52.9 \pm 43.1$ inds $\left./ \mathrm{m}^{3}\right)$ than in the KBW $\left(25.2 \pm 5.7 \mathrm{inds} / \mathrm{m}^{3}\right.$, Fig. 4$)$. In the present study, 73 species of copepods belonging to 36 genera, 18 families and 3 orders were identified (Table 2). According to the results of a cluster analysis, the sampling stations were divided into three groups, $\mathrm{KBG}, \mathrm{MG}$ and $\mathrm{CCG}$, at linkage dis- 
tance 25 (Fig. 5). Stations of group KBG (ST 1 and ST6 to ST8) located in the warm water area influenced by the $\mathrm{KBC}$, while the waters of group CCG was introduced by the CCC. And stations in group MG were situated in the mixing waters resulting from the KBC and CCC. Shannon diversity index and Simpson's evenness showed stations in groups KBG and MG with higher copepod diversity and evenness in contrast to those in the group CCG (Table 1 and Fig. 5). The dominant species in the KBC were Paracalanus aculeatus (47 inds $/ \mathrm{m}^{3}$ ), Acrocalanus gibber (20 inds $\left./ \mathrm{m}^{3}\right)$, Canthocalanus pauper $\left(15 \mathrm{inds} / \mathrm{m}^{3}\right)$, Clausocalanus furcatus (12 inds $\left./ \mathrm{m}^{3}\right)$ and Oithona plumifera $\left(12 \mathrm{inds} / \mathrm{m}^{3}\right)$. Where in the CCW were Paracalanus parvus (137 inds $\left./ \mathrm{m}^{3}\right)$, Paracalanus aculeatus (76 inds $\left./ \mathrm{m}^{3}\right)$, Acartia pacifica (40 inds $\left./ \mathrm{m}^{3}\right)$, Acrocalanus gibber $\left(40\right.$ inds $/ \mathrm{m}^{3}$ ) and Acartia pacifica (40 inds $\left./ \mathrm{m}^{3}\right)$. And in the MW, Paracalanus parvus $\left(71 \mathrm{inds} / \mathrm{m}^{3}\right)$, Paracalanus aculeatus (66 inds $\left./ \mathrm{m}^{3}\right)$, Acrocalanus gibber (46 inds $\left./ \mathrm{m}^{3}\right)$, Ditrichocorycaeus affinis $\left(29\right.$ inds $/ \mathrm{m}^{3}$ ) and Temora turbinata $\left(25\right.$ inds $\left./ \mathrm{m}^{3}\right)$ were dominant.

\section{DISCUSSION}

The marine environment of the area studied here is influenced by monsoon systems and bottom topography [21, 23]. The southward flowing CCW confronted the northward flowing $\mathrm{KBW}$ and forming a zonal oceanic front around the CYR in the middle of the strait [21, 27, 29]. There exists saline subsurface water with stable characteristics in the northern TS, following the T-S curves of the SCSC and KBC throughout the year [23]. The brackish CCC flowed into the study area and formed a thermocline with the saline subsurface water. The CCW received ample supply of nitrate from riverine discharges, most notably from Changjiang [45], with a maximum concentration of nutrients $\left(\mathrm{NO}_{3}\right)$ and $\mathrm{Chl}-\mathrm{a}$ at the surface decreasing with depth [12]. Liu et al. [30] also reported that nitrate fluxes were highest associated with the $\mathrm{CCC}$ in winter. In contrast to the $\mathrm{KBC}$ provides a strong western boundary current, with low nutrient concentrations flowing northward through the PHC into the TS in winter [6]. Copepods were abundant in the CCW and the FW in this study being associated with a sufficient support of available food. Species diversity and richness of copepods were higher in the KBW and FW but lower in the CCW in this study, and were similar to previous studies [15-16, 24, 38]. In our study, 73 species of planktonic copepods were found. This result is higher than the records of Hsieh and Chiu [14] (62 species) and Hsieh et al. [15] (70 species), but lower than reports of Lan et al. [24] (116 species) and Hsieh et al. [16] in the sampling periods when the CCC and the KBC existed at the same time. Unfortunately, the copepod abundance and diversity was probably underestimated by sampling with a 330- $\mu \mathrm{m}$ mesh net in this study. Gallienne and Robins, and Turner [11, 41] suggested copepod abundance and diversity would be underestimated by sampling with a mesh size of $200 \mu \mathrm{m}$ or greater due to losses of smaller organisms such as Oithona and Oncaea, as well as juvenile forms of larger copepods.

Copepods assemblages and distribution were associated with water masses [10, 15, 24, 38]. Our study also shows similar copepod assemblages in the same water masses (Fig. 5). Most dominant species in the group KBG where was influenced by the $\mathrm{KBC}$ have been recorded belonging to warm water species [7]. In this study, the KBC flows northward along the west coast of Taiwan and brought the tropical copepod, such as Calanoides carinatus into the southeastern TS Acrocalanus gibber, A. gracilis, Canthocalanus pauper, Clausocalanus furcatus have been reported belonging to tropical species [3], and were dominant in Kuroshio Current and the Taiwan Strait warm waters [28]. Acrocalanus gibber was abundant in summer and decreased in winter $[10,16]$. Canthocalanus pauper was also regarded as indicator species of the $\mathrm{KC}[10,15]$. Chihara and Murano [7] recorded Clausocalanus minor and Clausocalanus mastigophorus inhabiting in the tropical to the subtropical zone. Paracalanus aculeatus dominated in both the CCW and KW, and were similar to that recorded in Lan et al. [24]. Paracalanus acculeatus being an indicator species of the KBW belong to warm water species, but it was also recorded dominating the Tanshui River estuary in winter [14]. Dur et al. [10] reported Paracalanus aculeatus to be derived from a northwestern calanoid community from a cold water mass $\left(14 \pm 0.02{ }^{\circ} \mathrm{C}\right)$. Paracalanus parvus was dominant in the CCC and FC in this study, and was known to be widely distributed in most of the world ocean [35], and was abundant in coastal waters off China [3, 4]. Hsieh et al. [16] reported $P$. parvus to be more abundant in spring than in summer and early winter. Acartia pacifica was recorded with a wide temperature range but lower salinity [44], and also being dominant in the CCC. Calanus sinicus has been frequently the subject of study and was pointed out that its appearance usually coincided with the $\mathrm{CCW}$ and being its indicator species $[10,15]$. It is brought from the East China Sea to the Taiwan Strait and to the South China Sea in the winter-spring period [19, 24, 44]. Zheng et al. [44] reported that Calanus sinicus and Corycaeus (Ditrichocorycaeus) affinis were two of the coastal/neritic species with optimal temperature of no higher than $20{ }^{\circ} \mathrm{C}$, and were carried southward to the northern part of South China Sea by the CCW in winter. In the laboratory, Calanus sinicus survive between 5 and $23{ }^{\circ} \mathrm{C}$ [42]. Temora turbinata was reported to be abundant in coastal areas of Taiwan and in the vicinity of the river estuaries in spring and autumn [25, 44]. It was dominant in the CCC, and has been reported as an indicator species as the $\mathrm{KBC}[20,24]$. Therefore, Temora turbinata was restricted to neritic environment more then limited by temperature or salinity. The assemblage of copepods showed a high association with the distribution of water masses in our study, and would be useful for the understanding of copepod populations in winter.

\section{ACKNOWLEDGMENTS}

We thank the captain and crew of the Ocean Research vessel I and graduate students of this team of the Department of Environmental Biology and Fisheries Science, National Taiwan Ocean University, who helped with the collection of zooplankton samples and assemblage environmental data. This 
project (grant no. NSC90-2611-M-019-011-OP4) was financially supported by the National Science Council of Taiwan.

\section{REFERENCES}

1. Boucher, M., Ibanez, F., and Prieur, L., "Daily and seasonal variations in the spatial distribution of zooplankton populations in relation to the physical structure in the Ligurian Sea front," Journal of Marine Research, Vol. 45, pp. 133-173 (1987).

2. Charles, J. K., Ecological Methodlogy, University of British Columbia, Vancouver, pp. 654 (1989).

3. Chen, Q. C. and Zhang, S. Z., "The planktonic copepods of the Yellow Sea and the East China Sea. 1. Calanoida," Studia Marina Sinica, Vol. 7, pp. 20-133 (1965). (in Chinese)

4. Chen, Q. C., Zhang, S. Z., and Zhu, C. S., "On planktonic copepods of the Yellow Sea and the East China Sea. 2. Cyclopoida and Harpacticoida,' Studia Marina Sinica, Vol. 9, pp. 27-100 (1965). (in Chinese)

5. Chen, C. T. A., "Rare northward flow in the Taiwan Strait in winter: a note," Continental Shelf Research, Vol. 23, pp. 387-391 (2003).

6. Chen, C. T. A., "Does the Taiwan Warm Current originate in the Taiwan Strait in wintertime?" Journal of Geophysical Research, Vol. 111, doi:10.1029/2005JC003281 (2006).

7. Chihara, M. and Murano, M., "An illustrated guide to marine plankton in Japan,” Tokai University Press, pp. 649-1004 (1997).

8. Chuang, W. S., "A note on the driving mechanisms of current in the Taiwan Strait," Journal of the Oceanographic Society Japan, Vol. 42, pp. 355-361 (1986).

9. Chuang, W. S., "Dynamics of subtidal flow in the Taiwan Strait," Journal of the Oceanographic Society Japan, Vol. 41, pp. 65-72 (1985).

10. Dur, D., Hwang, J. S., Souissi, S., Tseng, L. C., Wu, C. H., Hsiao, S. H., and Chen, Q. C., "An overview of the Influence of hydrodynamics on the spatial and temporal patterns of calanoid copepod communities around Taiwan," Journal of Plankton Research, i97-i116 (2007).

11. Gallienne, C. P. and Robins, D. B., "Is Oithona the most important copepod in the world's oceans?" Journal of Plankton Research, Vol. 23, pp. 1421-1432 (2001)

12. Gong, G. C., Shiah, F. K., Liu, K. K., Wen, Y. H., and Liang, M. H., "Spatial and temporal variation of chlorophyll a, primary productivity and chemical hydrography in the southern East China Sea," Continental Shelf Research, Vol. 20, pp. 411-436 (2000).

13. Hsiao, S. H., Fang, T. H., and Hwang, J. S., "The bioconcentration of Ttrace metals in dominant copepod species off the northern Taiwan coast," Zoological Studies, Vol. 79, pp. 459-474 (2006).

14. Hsieh, C. H. and Chiu, T. S., "Copepod abundance and species composition of Tanshui river estuary and adjacent waters," Acta Zoologica Taiwanica, Vol. 8, pp. 75-83 (1998).

15. Hsieh, C. H., Chiu, T. S., and Shih, C. T., "Copepod diversity and composition as indicators of intrusion of the Kuroshio Branch Current into the northern Taiwan Strait in spring 2000," Zoological Studies, Vol. 43, pp. 393-403 (2004).

16. Hsieh, C. H., Chen, C. S., and Chiu, T. S., "Composition and abundance of copepods and ichthyoplankton in Taiwan Strait (western North Pacific) are influenced by seasonal monsoons," Marine and Freshwater Research, Vol. 56, pp. 153-161 (2005).

17. Hunter, J. R., "Feeding ecology and predation of marine fish larvae," Marine Fish Larvae, Lasker, R., ed., pp. 34-77 (1981).

18. Hwang, J. S., Chen, Q. C., and Wong, C. K., "Taxonomic composition, density and biomass of free-living copepods in the coastal waters of southwestern Taiwan," Crustaceana, Vol. 76, pp. 193-206 (2003).

19. Hwang, J. S. and Wong, C. K., "The China Coastal Current as a driving force for transporting Calanus sinicus (Copepoda: Calanoida) from its population centers to waters off Taiwan and Hong Kong during the winter northeast monsoon period," Journal of Plankton Research, Vol. 27, pp. 205-210 (2005).

20. Hwang, J. S., Souissi, S., Tseng, L. C., Seuront, L., Schmitt, F. G., Fang, L. S., Peng, S. H., Wu, C. H., Hsiao, S. H., Twan, W. H., Wei, T. P., Kumar, R., Fang, T. H., Chen, Q. C., and Wong, C. K., "A 5-year study of the influence of the northeast and southwest monsoons on copepod assemblages in the boundary coastal waters between the East China Sea and the Taiwan Strait," Journal of Plankton Research, Vol. 28, pp. 943-958 (2006).

21. Jan, S., Wang, J., Chern, C. S., and Chao, S. Y., "Seasonal variation of the circulation in the Taiwan Strait," Journal of Marine Systems, Vol. 35, pp. 249-268 (2002).

22. Jan, S. and Chao, S. Y., "Seasonal variation of volume transport in the major inflow region of the Taiwan Strait: the Penghu channel," Deep-Sea Research II, Vol. 50, pp. 1117-1126 (2003).

23. Jan S., Sheu, D. D., and Kuo, H. M., "Water mass and through flow transport variability in the Taiwan Strait," Journal of Geophysical Research, Vol. 111, doi:10.1029/2006JC003656 (2006).

24. Lan, Y. C., Shih, C. T., Lee, M. A., and Shieh, H. Z., "Spring distribution of copepods in relation to water masses in the nothern Taiwan Strait," Zoological Studies, Vol. 43, pp. 332-343 (2004).

25. Last, J. M., "The food of four species of pleuronectiform larvae in the Eastern English Channel and Southern North Sea," Marine Biology, Vol. 45, pp. 359-368 (1978).

26. Last, J. M., The Food of Twenty Species of Fish Larvae in the West-Central North Sea, Fisheries Resources Technical Report, MAFF Directorate of Fisheries Research, Lowestoft (1980).

27. Li, C. Y., Hu, J. Y., Jan, S., Wei, Z. U., Fang, G. H., and Zheng, Q. N., "Winter-spring fronts in Taiwan Strait," Journal of Geophysical Research Vol. 111, doi:10.1029/2005JC003203 (2006).

28. Liao, C. H., Chang, W. J., Lee, M. A., and Lee, K. T., "Summer distribution and diversity of copepods in upwelling waters of the southeastern East China Sea," Zoological Studies, Vol. 45, pp. 378-394 (2006).

29. Lin, S. F., Tang, T. Y., Jan, S., and Chen, C. J., "Taiwan Strait Current in winter," Continental Shelf Research, Vol. 25, pp. 1023-1042 (2005).

30. Liu, K. K., Tang, T. Y., Gong, G. C., Chen, L. Y., and Shiah, F. K., "Cross-shelf and along-shelf nutrient fluxes derived from flow fields and chemical hydrography observed in the southern East China Sea off northern Taiwan," Continental Shelf Research, Vol. 20, pp. 493-523 (2000).

31. Lo, W. T., Hwang, J. S., and Chen, Q. C., "Identity and abundance of surface-dwelling, coastal copepods of southwestern Taiwan," Crustaceana, Vol. 74, pp. 1139-1157 (2001).

32. Lo, W. T., Hwang, J. S., and Chen, Q. C., "Spatial distribution of copepods in surface waters of the southeastern Taiwan Strait," Zoological Studies, Vol. 43, pp. 218-228 (2004).

33. Lo, W. T., Chung, C. L., and Shih, C. T., "Seasonal distribution of copepods in Tapong Bay, southwestern Taiwan," Zoological Studies, Vol. 43, pp. 464-474 (2004).

34. Magurran, A. E., Ecological Diversity and Its Measurement, Chapman \& Hall, UK (1996).

35. Peterson, W., "Life cycle strategies of copepods in coastal upwelling zones," Journal of Marine Systems, Vol. 15, pp. 313-326 (1998).

36. Wang, J. and Chern, C. S., "On the Kuroshio branch in the Taiwan Strait during wintertime," Progress in Oceanography, Vol. 21, pp. 469-491 (1998).

37. Sanchez, V. L., "Diet composition and feeding habits of fish larvae of two co-occurring species (Pisces: Callionymidae and Bothidae) in the north-western Mediterranean," ICES Journal of Marine Science, Vol. 55, pp. 299-308 (1998).

38. Shih, C. T. and Chiu, T. S., "Copepod diversity in the water masses of the southern East China Sea north of Taiwan," Journal of Marine Systems, Vol. 15, pp. 533-542 (1998).

39. Tseng, W. Y., "Planktonic copepods from the waters off Tanshui," Bulletin of Taiwan Fisheries Research Institute, Vol. 25, pp. 1-44 (1975).

40. Tseng, W. Y., "Supplementary report on planktonic copepods from the waters off Tanshui, Taiwan," Bulletin of Taiwan Fisheries Research Institute, Vol. 26, pp. 105-112 (1976).

41. Turner, J. T., "The importance of small planktonic copepods and their roles in pelagic marine food webs," Zoological Studies, Vol. 43, No. 2, pp. 255-266 (2004).

42. Uye, S., "Temperature-dependent development and growth of Calanus sinicus (Copepoda: Calanoida) in the laboratory," Hydrobiologia, Vol. 167-168, pp. 285-293 (1988).

43. Xu, Z., "Relationships between population characters of Undinula vulgaris (Copepoda) and environment in the East China Sea," Ying Yong Sheng Tai Xue Bao, Vol. 17, pp. 107-112 (2006).

44. Zheng, C., Li, S. J., and Lian, G. S., "Marine copepod biology," Amoy University Press, pp. 312 (1992). (In Chinese)

45. Zheng, J., "Nutrient elements in large Chinese estuaries," Continental Shelf Research, Vol. 16, pp. 1023-1045 (1996). 